Ключевые слова: права человека, полиция, МВД, образовательный процесс, профессиональное обучение, компетентность, профессионализм, компетентностный подход.

\title{
Summary
}

Olha Barabash, Dmytro Zabzaliuk. The system of training future law enforcement officers in Ukraine: implementing the competence approach.

The article examines the features of training future law enforcement officers of Ukraine through the prism of the competence approach. It is noted that the state, acting as a reformer, sets the task of improving efficiency of the Ministry of Internal Affairs of Ukraine in ensuring security, protecting human rights and freedoms as the main goal of administrative reform, which requires considering the administrative activities structure of law enforcement bodies as an integral system. The principles of reforming law enforcement bodies, as related and universal categories, can be summarized as follows: the rule of law, depoliticization, demilitarization, decentralization, accountability and transparency, close cooperation with the public and local communities, professional training.

It is emphasized that the on-going reforms of law enforcement bodies greatly affect the process of professional training in educational institutions of the Ministry of Internal Affairs of Ukraine, as well as call for the quality of their professional culture and training, readiness to perform specific tasks requiring special knowledge, abilities, and skills. Today, graduates of educational institutions of the Ministry of Internal Affairs are required to show high professionalism, lawfulness, and humanity at the same time in the performance of their duties. According to many researchers, the best way to increase the efficiency of law enforcement bodies is to develop a theoretically substantiated system for the formation and development of professionalism of law enforcement officers. In addition, researchers emphasize that increasing role of a law enforcement officer requires a high professional self-awareness, the development of which is possible through the formation of a sense of responsibility for their actions, understanding the need for continuous improvement of their professional skills, taking into account the features of activities in particular units of law enforcement bodies and by developing new professional and psychological approaches to the training.

It is concluded that the reorientation to the competence approach in educational activities aims primarily to minimize the shortcomings of the disciplinary system of education, to expand knowledge as a result of the process of cognitive activity, abilities as the capability to perform certain work in accordance with knowledge acquired, skills as repetitive actions made automatic in the process of applying competence approach to education. In this case, according to a number of researchers, competence is understood as knowledge and experience necessary for effective activities in a given subject area, through matching with the requirements of the profession, as the professional's having the necessary amount of knowledge, abilities, and skills, constituting the basis for his or her professional activities, communication, and personality. The competence approach can be interpreted as a set of general principles for determining the goals of education, shaping educational programs, organizing the educational process, and evaluating educational results.

Key words: human rights, police, Ministry of Internal Affairs, educational process, professional training, competence, professionalism, competence approach.

DOI: 10.36695/2219-5521.3.2020.06

удК 340

\section{О.О. САМОЙЛЕНКО}

Олена Олександрівна Самойленко, кандидат юридичних наук, старший науковий співробітник, старший науковий співробітник Інституту держави і права імені В.М. Корецького НАН України*

ORCID: 0000-0002-4624-5105

\section{БІЛЯ ВИТОКІВ ЮВЕНАЛЬНОЇ ЮСТИЦІї - ЖИТТЯ ТА ДОЛЯ ВАЛЕРІЯ МИХАЙЛОВИЧА ЛЕВИТСЬКОГО}

Постановка проблеми. Останнім часом біографічні статті набувають все більшої актуальності. Це пов'язано з тим, що вивчення біографії людини є ефективним засобом пізнання крізь призму історії окремої особистості того історичного соціуму, в якому вона жила, творила, любила, напрацьовувала власний життєвий досвід. Завдяки такому дослідженню відбувається занурення в життя героя, в конкретну історичну епоху й ситуацію. Таке дослідження дає можливість простежити динаміку внутрішнього світу людини, показати історію особистості у взаємодії з іншими постатями, з культурними та інтелектуальними традиціями. Відобразити, як вплинули соціальні, політичні та історичні події на прийняття тих чи інших особистих рішень.

Формування мети статті. Метою даного дослідження є: 3'ясувати та відкрити завісу в біографії Валерія Михайловича Левитського - першого судді київського суду для малолітніх, талановитого юриста, журналіста, громадського діяча, політичного аналітика, відомого кадета.

Виклад основного матеріалу. Майбутній суддя народився 12 травня 1886 р. у місті Галич Костромської губернії. Його ім'я, як і багато інших, ми нині повертаємо з прірви забуття. Завдяки введенню в обіг

() О.О. Самойленко, 2020

* Olena Samoilenko, Ph.D. in Law, Senior Researcher, Senior Researcher of V.M. Koretsky Institute of State and Law of the NAS of Ukraine

Часопис Київського університету права • 2020/3 
нових архівних матеріалів вчені мають змогу відкрити завісу в біографії В.М. Левитського. У 1909 р. Валерій Михайлович закінчив юридичний факультет Київського університету Св. Володимира із дипломом першого ступеню. Ще у студентські роки він долучився до громадської діяльності Товариства Київського Патронату. Насамперед зазначимо, що київський період творчості Левитського був досить плідним. Здебільшого він займався питаннями піклування про безпритульних дітей та дітей ув'язнених. Одним із головних завдань Товариства була боротьба зі злочинністю найбільш доступною і сучасною зброєю - вирвати дітей із злидень, жахливого оточення та з несприятливого впливу навколишнього середовища.

Валерій Михайлович досить активно просував ідею створення суду для малолітніх у Києві. Він всім серцем віддавався громадській діяльності. Ідея про зародження судів для дітей зародилася ще в Австралії, але широке застосування вона знайшла в США. Маючи гарні результати, ідея створення суду для малолітніх була перенесена до Західної Свропи - спочатку до Англії, потім до Німеччини, Франції і в 1910 р. в порядку експерименту була реалізована в Росії в Санкт-Петербурзі. Згодом таки суди з'явилися в Харкові і Одесі. А приводом введення такого суду було велике зростання злочинності наприкінці ХІХ ст. у всьому світі. Кількість юних злочинців не тільки зросла, а й обганяла злочинність дорослих груп населення. Так, за час із 1874-1894 pp. їх кількість зросла в Росії на 18 \%, у Сполучених Штатах Америки за 1889-1897 pp. - на 25 \%, в Італії за $1895-1899$ рр. - на $12 \%{ }^{1}$.

За результатами діяльності особливого суду для малолітніх в Петербурзі було вирішено вжити заходів до запровадження такого ж суду в Києві. Для цього були прочитані лекції в спеціальному засіданні правління за участю представників мирової юстиції та міського самоврядування, лектори - Ю.П. Новицький та B.М. Родів. Також було складено доповідну записку в Київську міську думу про необхідність допомоги 3 боку міського самоврядування для введення названого суду в Києві. У Київську міську думу було подано особливу доповідь, у якій детально були розписані витрати на суд для малолітніх. Процес організації суду затягнувся на довгих чотири роки.

На загальному зібранні, 27 квітня 1912 р., Валерій Михайлович був обраний разом із Ю.П. Новицьким кандидатом у члени правління Товариства Київського Патронату․․ На засіданні Левитський виступив із доповіддю «Про суд для малолітніх». Особливе Зібрання Патронату визнало введення дитячого суду в Києві наполегливо необхідним і доручило правлінню розробити проєкт Положення про нього. До першого січня 1913 р. проєкт було розроблено і внесено на розгляд Київського з’їзду мирових суддів. Після чого 3 незначними змінами він був поданий до 1-го Департаменту Міністерства юстиції. У грудні 1913 р. Міністерство юстиції схвалило проєкт, а 7 січня 1914 р. Київський міський з’їзд мирових суддів ухвалив розглядати усі справи щодо малолітніх обвинувачених і малолітніх потерпілих в окремому суди. Усі справи були виділені та доручені додатковому мировому судді.

Суддею в суді для малолітніх призначався додатковий суддя, який не був пов’язаний певною ділянкою, на становищі відрядженого на допомогу всім дільничним суддям у справах даної категорії, що виникають у мирових суддів. Суддя повинен був мати особливу підготовку. Велика увага приділялася ролі та значенню особистості судді для успіху всієї справи. На думку правозахисниці Олени Гінзбург ${ }^{3}$, вдалий вибір судді визначить долю всього починання. Ігнорування ж цього питання може привести до створення установи абсолютно нежиттєздатної. Суддя повинен підійти до дитини з любов'ю та інтересом, вміло проникнути в ії хвору, озлоблену душу, розібратися з їі переживаннями і визначити необхідні заходи, які сприятливо вплинуть на дитину. А з цим завданням можуть впоратися лише деякі.

Суддею київського суду для малолітніх був обраний молодий, талановитий, досвідчений мировий суддя Валерій Михайлович Левитський. Інформація щодо дати призначення В.М. Левитського додатковим мировим суддею дещо неточна. Так, в одних джерелах вказується, що він був призначений мировим суддею у справах малолітніх 20 грудня 1913 p. ${ }^{4}$, а в інших - 7 січня 1914 р. ${ }^{5}$ Це дає нам простір для подальших досліджень і заповнення існуючих лакун. Таким чином, завдяки появі особливого суду для малолітніх усувалася можливість появи малолітніх у загальних судах. У сфери його діяльності входили всі справи, за якими неповнолітні від 10 до 17 років звинувачувалися в скоєнні злочинів та були підсудні мировим судовим установам. Основна ідея - заміна репресії щодо дітей, які вчинили злочин, виправно-виховним початком. У цьому успіх нового судового інституту!

Розпочинати будь-яку нову справу завжди нелегко. Як писав сам Валерій Михайлович, перший рік діяльності суду - це був час, коли мировий суддя у справах малолітніх працював, навчаючись у житті. Основні зусилля були спрямовані на організацію підтримки життя юних порушників норм кримінального права та захист їх прав 6.

Пізніше Левитський у своїх спогадах так напише про цей період у своєму житті: «...Разом 3 невеликою групою чудових, чистих людей я старанно працював в Особливому суді для неповнолітніх ... як багато душевної бадьорості і свіжості вкладалося тоді в нову справу любовного виправлення «нічиїх» дітей. Роботи було по горло. Камера жила своїм власним життям. В успіху справи не сумнівалися ... вірили в перемогу на фронті ... всі міцно любили свій Київ»7.

Київ знаходився близько до фронту, тому суду доводилося рахуватися з особливими умовами воєнного часу. У 1915 р. суд змушений був реорганізовувати свою роботу заново і пристосовуватися до особливих умов. Половина малолітніх, з якими мав справу суд, були доставлені з фронту. Вони тікали зі свої сімей і рвалися на фронт. Усі громадські сили міста були кинуті на роботу в госпіталях та роботу з біженцями. Лише наприкінці 1915 р. вдалося заснувати додатково посаду третього штатного піклувальника і завдяки згоді 
Київської губернської земської Управи збільшити на 1916 р. асигнування вдвічі зі штрафних сум на обладнання та утримання житла для бездомних дівчат ${ }^{8}$.

До 1916 р. Левитський вже відав усіма установами для біженців-підлітків в районі Південно-Західного фронту і займався організацією допомоги дітям, які постраждали від військових дій. Також залишався активним членом правління Київського Патронату, членом правління та ревізором Товариства київських виправних колоній. Незважаючи на свою зайнятість, він не полишав освітню діяльність. Так у 1916 р. В.М. Левитський читав курс для шкільних лікарів «Охорона дитинства та боротьба 3 дитячою злочинністю» на курсах Київського Фребелевського суспільства* .

Не полишав Валерій Михайлович і ідею про наукову кар'єру. Мріяв стати професором. Ще у 1912 р. він був залишений для приготування до професорського звання в Київському університеті при кафедрі кримінального права. За цей час В.М. Левитський видав багато статей та звітів про діяльність суду для малолітніх, які були зараховані йому у якості наукової роботи. Валерій Михайлович був чудовим лектором, про що свідчать спогади студентів, присутніх на його лекціях 9 . Вчений комітет Київського університету Св. Володимира у 1916 р. так відгукнувся про роботу професорського стипендіата: «... Можна зробити висновок, що в особі В.М. Левитського ми маємо люблячого свою справу, освіченого судового діяча. ... Чи буде він тільки добре підготовленим судовим діячом або ж професором - про це можна буде сказати тільки після магістерського іспиту»10. На жаль, мрія В.М. Левитського не збулася. Стати професором Валерію Михайловичу не судилося. 1917 р. змінив не тільки його долю, а й долі багатьох інших людей.

У 1917 р. в його житті відбувається багато подій. Валерій Михайлович бере активну участь на політичній арені. Так, у липні 1917 р. він увійшов до виборчого списку кадетів на виборах у Київську міську думу. Але гласним так і не став, оскільки не набрав голосів. Але вже у серпні він став членом Української Центральної Ради. Наприкінці року Левитський брав участь у виборах до Українських Установчих зборів. Він очолив виборчий список партії народна свобода у Волинській губернії. На жаль, кадети у Волинській губернії набрали 1891 голос, що становило 0,48 \% і не отримали жодного мандата ${ }^{11}$. Розчарований у невдачах та незадоволений німецькою окупацією і гетьманом П.П. Скоропадським, Левитський шукав однодумців і знайшов їх у обличчі редактора газети «Киевлянин» ${ }^{* *}$ - В.В. Шульгіна та його прихильників. Є припущення, що В.М. Левитського познайомив із В.В. Шульгіним професор київського університету Г.В. Демченко, який свого часу писав відгук на наукову роботу Левитського. Згодом Шульгін почав видавати нову газету «Голос Києва» і запросив на роботу Валерія Михайловича. На сторінках нової газети він висловлював свою думку з різних політичних питань у циклі статей «Единий російський фронт».

Про рівень поваги та авторитет судді для малолітніх свідчить цікавий випадок, що стався із Левитським, коли прийшли у місто більшовики. Валерій Михайлович на той час мешкав у готелі. Рано-вранці його розбудив швейцар і сказав, що його вимагають солдати, шумлять, погрожують вбити! Левитський вийшов у вестибюль. Його оточили 17 людей з гвинтівками і кулеметними стрічками, офіцерськими шаблями ... Відразу впізнав старих знайомих. Це були кишенькові злодії з виховної колонії, поміщені туди окружним судом. Багато з них у ранній молодості пройшли і через Левитського. Валерій Михайлович запитав; «Шо потрібно? Паспорти зі старих справ? У Камеру приходьте!» Цього вони ніяк не очікували. «Ідіть, зараз я туди прийду», - додав. У відповідь - радісні посмішки: «Покірніше дякуємо, пане мировий суддя». I Левитський зачинив двері. А погрожували вбити! 12

Ще одним показовим був випадок, коли було прийнято рішення щодо скасування суду. Левитський та його підлеглі хвилювалися за долю міцної, любов'ю спаяної організації, за цілісність казенного майна. Приїхав комісар, став вимагати керівника. Комісаром «юстиції» виявився студент, син одного із приватних повірених, Левитський його знав. При зустрічі він був сильно збентежений, не знав, з чого почати ... тут же сказав, що він лівий есер, що не більшовик ... виправдовувався ... тимчасово погодився ... Валерій Михайлович заспокоїв його, сказав, що знайомий з їх декретом і їм потрібно врегулювати рахунки. Комісар вибачаючись підписав всі асигновки і поїхав. Камера продовжувала працювати. Міліція і червоноармійці продовжували доставляли до суду «старих друзів». Гроші на утримання суду були ще від Тимчасового уряду. За свідченням Левитського, українці не дали суду ні копійки.

Як вже зазначалося вище, В.М. Левитський був одним із лідерів національно-російської групи кадетів. Він продовжував активну політичну діяльність, не поривав зв'язок з партією. У цей час Левитський пише заклик до киян щодо боротьби з петлюрівцями. Однак у грудні 1918 р. гетьман капітулював, і добровольчі загони були роззброєні петлюрівцями, а Левитський та інші лідери Російського національного центру були змушені бігти в Одесу. Одеса в той час була зайнята білими і військовим контингентом Антанти.

\footnotetext{
* Фребелевські спільноти - спільноти діячів дошкільного виховання, що ставили за мету поширення системи Ф. Фребеля. Засноване в 1908 р. в Києві фребелевська спільнота почала свою діяльність влаштуванням Фребелевського педагогічного інституту з трирічним навчанням для підготовки виховательок. Єдине педагогічне ціле з ним становили педагогічні та психологічні лабораторії, опорні дитячі сади і дитячий притулок для немовлят і дітей до трирічного віку. Після Жовтневої революції 1917 р. фребелевські спільноти в Росії припинили існування. Петроградські фребелевські курси були перетворені на інститут дошкільної освіти, а Київський фребелевський інститут - на інститут народної освіти.

** «Киевля́нин» - російська приватна газета консервативно-монархічно-москвофільського та українофобського спрямування, що виходила в Києві російською мовою з 1864 по 1919 рр. Газета мала спочатку помірно-ліберальне, а згодом - консервативне монархічно-москвофільське спрямування. Була однією із найвпливовіших у Південно-Західному краї і однією 3 найкращих провінційних газет у всій Російській імперії.
} 
В Одесі Валерій Михайлович стає секретарем Підготовчої з національних справ комісії і входить до складу ради Південноросійського національного центру. Левитський не припиняє публіцистичну діяльність. Він активно працює в одеському виданні газет Шульгіна «Росія», а після іiї закриття - в газеті «Південна Русь». Навесні 1919 р. він перебирається в Катеринодар, де продовжує свою журналістську кар'єру, ставши редактором газети «Велика Росія».

Він пише передові ідеологічні статті в циклі «Руський державний націоналізм», нариси мемуарного характеру, веде окрему рубрику побутових замальовок «Мій блокнот». Паралельно Левитський працює над книгою «Руський державний націоналізм». Одну з глав книги йому вдалося опублікувати на сторінках видання «Голос Києва». Книга складалася з дев'яти глав. Перша глава - замість передмови, друга - Державний націоналізм на Заході, третя - Руський державний націоналізм в минулому. четверта - Особливості його, п'ята - Російська інтелігенція і проблема націоналізму, шоста - Відродження націоналізму нової Росії, сьома - Національне виховання, восьма - Державний націоналізм і наші політичні партії, дев'ята - Націоналізм і культурне відродження Росії13. На жаль, реалізувати задумане не вдалось, книга так і не побачила світ. У грудні 1919 р. білий фронт впав, червоні захопили Ростов-на-Дону, де жив і працював в той час Валерій Михайлович, і редакція «Великої Росії» змушена була евакуюватися в Новоросійськ. На початку 1920 p. біла армія доживала останні тижні свого існування на Кубані. А 22 лютого видання газети «Велика Росія» було припинено. Левитський в цей час захворів на тиф, але встигнув евакуюватися до Криму, де й відродив в Севастополі газету «Велика Росія». Прихід до влади П.М. Врангеля надихнув у нього оптимізм і надію на благополучний результат хоча б в ідейному та духовному сенсі.

Газета «Велика Росія» стала провідною білою газетою. Сам П.М. Врангель у мемуарах писав: «За винятком однієї серйозної газети «Велика Росія», що видавалася під редакцією В.М. Левитського та за участю М.М. Львова, М.М. Чебишева і В.В. Шульгіна, інша преса була типово дрібно провінційною» 14.

3 Криму вся редакція газети разом з Російською армією евакуювалася до Константинополя. Починається новий етап у житті Левитського. Протягом 1921 р. він займає посаду викладача в місцевому російському ліцеї. Одночасно друкується у журналі «Зірниці». Наприкінці 1921 р. побачила світ його невеличка книга «Про любов до батьківщини та народну гордість» ${ }^{*}$ Книга вийшла дуже захоплююча. По суті це були його бесіди з друзями під час прогулянок Константинополем. Автор вів діалоги на тлі відомих Константинопольських урочищ, у нього спостерігався дивовижний дар пейзажу. В.М. Левитський блискуче передав всі думки, що хвилювали російських людей на чужині. Треба зазначити, що книга отримала хороші відгуки в пресі.

На початку 1922 р. В.М. Левитський разом з Врангелем та його оточенням переїхав та мешкав у Сремських Карловцях, де він був начальником інформаційного відділу штабу Російської армії, а восени перебрався до Чехословаччини в місто Моравська Тршебова. Тут тривалий час він залишався без роботи і тільки восени 1923 р. отримав посаду позаштатного викладача законознавства, філософської пропедевтики та історії в місцевій російській гімназії. Грошей на проживання катастрофічно не вистачало. Рятувала тільки зарплата дружини Марії Опанасівни Левитської (1889-1983рр.), яка працювала і займала штатну посаду в тій же гімназії.

Саме в цей час Левитський намагався видати свою книгу «Боротьба на Півдні», яка була написана в 1922-1923 pp. і відображала реальні події в Росії після 1917 р., але, на жаль, безуспішно. Матеріальне становище його сім'ї було настільки скрутним, що він погодився на пропозицію старого друга по роботі у Києві та Одесі Л.Ф. Магерівського, який працював у РЗіА**, продати рукопис і ряд документів. За спогади Левитського була запропонована сума 1500 крон. I хоча В.М. Левитський розраховував на більш велику суму, погодився й на цю. Після смерті, у 1946 р., рукописи й документи (копії листів Врангеля і Денікіна) з колекції РЗіА були передані в СРСР. Зараз вони зберігаються в Державному Архіві Російської Федерації в фонді «Колекція окремих документів і мемуарів емігрантів». У повному обсязі його книга побачила світ лише в $2019 \mathrm{p}$.

Тільки в 1925 р. Валерію Михайловичу вдалося зайняти посаду штатного викладача Російського педагогічного інституту ім. Я.А. Каменського, де до 1927 р. він читав курс «Охорона дитинства та дитяча злочинність». Наприкінці року він перебрався жити до столиці Франції в Париж, де повернувся до активної журналістській роботи на сторінках паризького «Відродження». 3 того часу він став постійним паризьким кореспондентом багатьох російських газет інших країн. Так, Валерій Михайлович активно публікувався в софійській газеті «Голос Росії», в журналі «Армія і флот» тощо. Основною темою публікацій був Радянський Союз. У 1930 -і pp. В.М. Левитський - учасник російських національних організацій, активно співпрацював з РЗВС, викладав в офіцерській школі РЗВС (Російський Загально-Військовий Союз) російська військова організація, створена 1 вересня 1924 р. в Білій еміграції Головнокомандувачем Російської Армії генерал-лейтенантом бароном Петром Врангелем). Союз об'єднував військові організації і військові союзи у всіх країнах Російського Зарубіжжя. Добровольці з РЗВС вели підпільну роботу на теритоpiï CPCP.

\footnotetext{
* Левитский В. О любви к отечеству и народной гордости. Беседы. Царьград, 1921.

** Руський закордонний історичний архів у Празі (РЗіА) - найбільший з архівів російської еміграції в Європі міжвоєнного періоду. Існував у 1923-1945 pp.
} 
До кінця 1930-х рр. В.М. Левитський видав за свій рахунок кілька невеликих брошур-оглядів під загальною назвою «Міжнародне становище, сучасна Росія і життя в еміграції» ${ }^{*}$. Особливий інтерес становить огляд українського питання. У ньому детально описані події Громадянської війни в Україні, радянська політика «українізації». Так само проводиться характеристика різних груп української еміграції - від петлюрівців і гетьманців до організації українських націоналістів (ОУН) та католицьких і уніатських структур. У сорокові роки В.М. Левитський вже менше друкувався, його спіткало багато розчарувань. На його думку, з приходом до влади німців починається новий етап в житті емігрантів, і вони як ніколи повинні активно працювати над своєю національною й політичною підготовкою. Левитський розчарувався в німцях і майже не брав участі в суспільно-політичному житті. Остання його публікація була видана в берлінській газеті «Нове слово» у вересні $1940 \mathrm{p}$.

Помер Валерій Михайлович Левитський 27 квітня 1946 р. в Парижі. Був похований на кладовищі в паризькому передмісті Levallois. Згодом, 13 лютого 1983 р., через 37 років, там була похована його дружина Марія Опанасівна Левитська ${ }^{15}$. У наступному 2021 р. - 135 років 3 дня народження Валерія Михайловича Левитського.

Висновки. Ось така нелегка доля спіткала першого суддю київського суду для малолітніх. На прикладі біографії людини ми змогли не тільки дізнатися історію його життєвого шляху, а й зануритися в епоху, яка показала нам його взаємодію з іншими людьми, ситуацію, що склалася в суспільстві, в якій він жив і творив, специфічні обставини в житті його та держави. Ми побачили, яку роль вони зіграли в долі Валерія Михайловича Левитського, як вплинули на його особистий вибір, до яких дій і вчинків призвели. Валерія Михайловича можна віднести до числа людей, які не прийняли революцію і брали активну участь у Білому русі. 1917 р. круто змінив його життя. Надалі робота за фахом була неможлива, тому Левитський активно проявив себе на ниві журналістики. Відбулася свого роду конкретизація моменту на конкретній людській долі.

Можливо, дане дослідження ще трохи наблизить нас до розуміння трагічних подій того часу.

1 Тарасова Е.Л. Детский суд за границей и в России. Москва, 1912. С. $3,15$.

2 Отчет за 1912 год. Киевский Патронат (О-во покровительства лицам, освобождаемым из мест заключения г. Киева). Типография 1-й Киевской артели Печ. дела, Трехсвятительская, 5. Киев, 1912. С. 7. C. 109.

${ }_{3}^{3}$ Гальперина-Гинзбург Е.А. Под знаменем права. Сборник статей. Предисловие и редакция А. Кизеветтер. Берлин, 1923.

4 Левитский В.М. Борьба на Юге. Факты, Люди. Настроения. Москва, 2019. С. 6.

5 Левитский В.М. Суд для малолетних в Киеве за 1914 год. Приложение к отчету Киевского Патроната за 1914 год. Киев, 1915. C. 2

6 Там само. С. 2.

7 Левитский В.М. Борьба на Юге. Факты, Люди. Настроения. Москва, 2019. С. 41.

8 Левитский В.М. Детский суд и война (второй год деятельности особого суда для малолетних в Киеве). Киев, 1916. С. 7.

9 Державний архів м. Києва. Ф. 16. Оп. 465. Д. 4103. С. 2.

10 Левитский В.М. Борьба на Юге. Факты, Люди. Настроения. Москва, 2019. С. 7.

${ }^{11}$ ЦДАВО України. Ф. 1133. Оп. 1. Спр. 26. Арк. 30.

12 Левитский В.М. Борьба на Юге. Факты, Люди. Настроения. Москва, 2019. С. 53.

13 Там само. С. 15.

14 Врангель П.Н. Записки (ноябрь 1916 - ноябрь 1920 г. Белое дело: Летопись белой борьбы. 1928. Кн. 6. С. 122.

15 Незабытые могилы, Российское зарубежье некрологи 1917-1997 гг.: в 6 т. / В.Н. Чуваков, сост. Москва, 2004. Т. 4. С. 96.

\section{Резюме}

Самойленко О.О. Біля витоків ювенальної юстиції - життя та доля Валерія Михайловича Левитського.

У статті розглядаються основні віхи життєвого і творчого шляху Валерія Михайловича Левитського, одного із активних учасників Товариства Київського Патронату, мирового судді, першого судді київського суду для малолітніх, журналіста - у контексті суспільно-політичних процесів першої половини XX ст. Представлено його наукову, політичну та громадську позиції до і після $1917 \mathrm{p}$.

Ключові слова: Товариство Київський Патронат, Київський суд для малолітніх, додатковий мировий суддя, кадет, Білий рух, еміграція.

\section{Резюме}

Самойленко Е.А. У истоков ювенальной юстиции - жизнь и судьба Валерия Михайловича Левитского.

В статье рассматриваются основные вехи жизненного и творческого пути Валерия Михайловича Левитского, одного из активных участников Общества Киевского патронатом, мирового судьи, первого судьи киевского суда для малолетних, журналиста - в контексте общественно-политических процессов первой половины XX в. Представлены его научная, политическая и общественная позиции до и после 1917 г.

* Левитский В.М. Советская молодежь. Париж, 1935; Красная власть и белая Россия. Париж, 1935; Планы разложения эмиграции. Париж, 1936; Что происходит в России. София, 1936; Что же нам делать? Париж, 1938; Что каждый должен знать об Украине. Часть 1. Париж, 1939; Что каждый должен знать об Украине. Часть 2. Париж, 1939; Украинская Республика и самостийники за границей. Париж, 1939. 
Ключевые слова: Общество Киевский Патронат, Киевский суд для малолетних, дополнительный мировой судья, кадет, Белое движение, эмиграция.

\section{Summary}

Olena Samoilenko. At the origins of juvenile justice - the life and fate of Valery Mikhailovich Levitsky.

The article reviews main milestones in the life and creative work of Valery Mikhailovich Levitsky, one of the active members of the Kyiv Patronage Society, justice of peace, first judge of the Kyiv Juvenile Court, journalist - in the context of social and political processes of the first half of the twentieth century. His scientific, political and public positions before and after 1917 are presented.

The future judge was born on May 12, 1886 in the city of Halych, Kostroma province. In 1909, Valery Mikhailovich graduated from the Law Faculty of St. Volodymyr Kyiv University with a first-class honors degree. While still a student he joined the public activities of the Kyiv Patronage Society. First of all, we note that the Kyiv period of Levitsky's creative activity was quite fruitful. He mainly dealt with problems of caring for homeless children and children of prisoners. He was elected a justice of peace, and in late 1913 and early 1914 a judge of the Kyiv Juvenile Court.

By 1916, Levitsky was in charge of all adolescent refugee facilities on the Southwestern Front and organized assistance to children affected by the war. He also remained an active member of the Kyiv Patronage Board, a member of the Board and auditor of the Kyiv Correctional Colony Society. Back in 1912, he was left to prepare for a professorship at the Department of Criminal Law of the Kyiv University. During this period, he published many articles and reports on the activities of the juvenile court, which were credited to him as his academic papers.

In 1917, many events took place in his life. Valery Mikhailovich takes an active part in the political scene. Thus, in July 1917 he was included in the electoral list of cadets for the Kyiv City Duma elections. But he did not become a vowel because he did not get enough votes. However, in August he became a member of the Ukrainian Central Council. At the end of the year, Levitsky took part in the elections to the Ukrainian Constituent Assembly.

Disappointed in failures and dissatisfied with the German occupation and Hetman P. Skoropadsky, Levitsky was looking for likeminded people and found them in the person of the editor of the newspaper «Kievlyanin» - V. Shulgin and his supporters.

Valery Mikhailovich can be attributed to those who did not accept the revolution and took an active part in the White Movement. The year of 1917 dramatically changed his life. Then there was emigration. The further work in the specialty was impossible, so Levitsky actively proved himself in the field of journalism. Valery Mikhailovich Levitsky died on April 27, 1946 in Paris. Perhaps this study will bring us a little closer to understanding the tragic events of that time.

Key words: Kyiv Patronage Society, Kyiv Juvenile Court, Additional Magistrate, Cadet, White Movement, Emigration.

DOI: 10.36695/2219-5521.3.2020.07

УДК 340.1

\section{0. ШАНДУЛА}

Олександр Олексійович Шандула, кандидат юридичних наук, доцент Національного юридичного університету ім. Ярослава Мудрого, адвокат*

ORCID: 0000-0002-8055-0138

\section{АДВОКАТСЬКА МОНОПОЛІЯ: НАЦІОНАЛЬНІ ТЕНДЕНЦІЇ ТА ЗАРУБІЖНИЙ ДОСВІД}

Актуальність теми зумовлена подальшими процесами становлення в Україні громадянського суспільства і правової держави, що висуває на перший план проблему забезпечення прав і свобод людини та громадянина. Реалізація закріпленого в Конституції України положення про найвищу цінність прав і свобод людини та громадянина неможлива без ефективної системи загальних і спеціально-юридичних гарантій їх забезпечення. Юридична допомога $є$ одним із важливих юридичних засобів, необхідним елементом механізму забезпечення прав і свобод. Досить часто пересічні громадяни, які не мають спеціальних юридичних знань та навичок, щоб ефективно використовувати правові засоби для реалізації і захисту своїх інтересів, потребують фахової допомоги юриста-професіонала.

Економічні і соціально-політичні перетворення в сучасній Україні привели до виникнення якісно нових суспільних відносин, демократизації форм і методів їх регулювання. 3 огляду на це зросла потреба суб'єктів суспільних відносин в отриманні кваліфікованої юридичної допомоги, цінність якої як соціального блага полягає, зокрема, в тому, що особа особливо відчуває в ній необхідність саме в разі порушення ії суб'єктивних прав. Тому важливим елементом змісту права на кваліфіковану юридичну допомогу є iї надання насамперед під час захисту прав і свобод людини та громадянина.

Традиційно потреба в наданні юридичної допомоги пов'язана з участю осіб у кримінально-правових і кримінально-процесуальних відносинах. При цьому потрібно зазначити, що в останнє десятиліття істотно розширилося коло підстав надання юридичної допомоги у зазначеній сфері. 3 розвитком цивільних та інших

(c) О.О. Шандула, 2020

* Oleksandr Shandula, Ph.D. in Law, Associate Professor of Yaroslav Mudryi National Law University 